https://jurnal.ugm.ac.id/rubikon

\title{
THE FORM OF SENSUALITY IN HISPANIC MUSIC IN AMERICAN MUSIC INDUSTRY: DISCOURSE ANALYSIS ON AMERICAN POPULAR MUSIC
}

\author{
Maria Elfrieda C.S.T \\ e-mail: maria.elfrieda.c@mail.ugm.ac.id \\ Ida Rochani Adi \\ Universitas Gadjah Mada \\ e-mail: idaadi@ugm.ac.id
}

\begin{abstract}
In 2017 and 2018, Hispanic music reaches high popularity as world music. The reaction came from the American music industry, seen through the production of Hispanic music in American music industry, which brings Hispanic music as a part of American popular music. In this case, American popular musicians started to produce music that contains Hispanic music characteristics. Among all of the characteristics, the form of sensuality becomes a significant aspect in producing Hispanic music, even in American music industry. In relation to this fact, this research is conducted in order to see how the form of sensuality supports the popularity of Hispanic music. The theory of Discourse Analysis by Michel Foucault is applied to analyze sensuality as adiscourse behind the popularity of Hispanic music. As a research conducted within the frame of American Studies, this research also usesthe postmodern approach to see the new formula related to the form of sensuality in Hispanic music, especially when produced in the American music industry.
\end{abstract}

Keywords: American popular music; Hispanic music; machismo; women sexual objectification; women sexual subjectification

DOI $\quad$ : https://doi.org/10.22146/rubikon.v7i1.62512

Available at https://jurnal.ugm.ac.id/rubikon/article/view/62512

This work is licensed under a Creative Commons Attribution-ShareAlike 4.0 International License

\section{INTRODUCTION}

Historically, the idea of Hispanic music as erotic music arises when music such as Rumba is introduced in Cuba, which also attracted North America. In his book titled On Becoming Cuban: Identity, Nationality, and Culture, Pérez (2012) explains how Rumba
Article information

Received: 14 January, 2020

Revised: 28 January, 2020

Accepted: 11 February, 2020 
Music served as both source and setting of the North American meditation on sex and sensuality. [...] The music was necessary to the pursuit of romance and seduction. [...] Sensuous music, stimulating primitive impulses, aroused romantic urges (ibid).

The erotic image of Hispanic music is developed even since this kind of music was introduced to the North Americans or Cubans, which can be seen through the attraction came from the people towards the music. In this case, they can also see the erotic aspect of the music through the movement of the music itself. Moreover, in this situation, the North Americans or Cubans found the enjoyment, especially towards the erotic vibe they found in the music. The erotic formula or the sensuousness in the music is taken as the medium for expressing romance or seduction.

The erotic formula has its contribution for the popularity of Hispanic music, especially in American music industry. In this case, through its development, Hispanic music is well known or popular with its erotic vibe. The erotic formula is so important and significant that American music industry also put it into their consideration when creating or producing Hispanic music. It can be seen through various Hispanic music industry produced in American music industry in 2017 and 2018. The erotic formula itself can be found through the elements of the music. Moreover, it can be seen how the American music industry tries to keep the characteristics of Hispanic music as authentic as possible by keeping the authentic formulas, including bringing out the erotic vibe of Hispanic music. In relation to this formula, the discussion on this subchapter will look into the elements of Hispanic music produced in American music industry specifically to see the erotic formula and to see how it supports the popularity of Hispanic music in American music industry.
American Popular Music

Regarding to the issue of this research, the Postmodern approach within the frame of American Studies seems relevant. As an interdisciplinary study, this research is also conducted under American studies using Discourse Analysis theory. This theory focuses on how the discourses of knowledge is constructed through language in the mass media and how those discourses compete to each other in resulting the powerful discourse which is later believed as the 'truth' by the society.The existence of discourse is limited depends on the social context that happened in a certain period of time. It is stated that discourse is the part of history shows that, together with the social dynamic or social change throughout the history, the discourse might be replaced by another discourse more 'suitable' with the social condition during certain period of time.

In case of analyzing the musical elements, the concept of musical discourse analysis shows how music becomes the media for communicating through the elements of music and the intentions behind the production of musical art in order to depict social context.Related to the existence of discourse, power has a major role in the process of producing discourse. This can be seen through the relation between power and knowledge. These two things are inseparable, especially in producing discourse.It can be understood that the existence of power is not only limited in controlling or forcing the society but also in producing things, particularly, a discourse. Through this, the discursive process where power produces discourses is aimed to see how the discourse is accepted by the society as the 'truth'.

The construction of the 'truth' itself is not separated from the role of discourse as the representation of the reality. The reality that is 
seen or experienced is the result or the product of discourse. It is the result of how the world is seen within a certain perspective and the result of how preconceived knowledge about the world is used. In this case, the preconceived knowledge is used to construct the reality and the discourse behind it, which will make it more meaningful as the representation of the reality itself. Finally, the power of the discursive process might result on the impression that the discourse produced through this process is the 'truth'. In this situation, the knowledge about the world or the discourse would not stop on being the representation of the reality, but later on it might become the 'truth' for the society. Through this, then the society might see the distinction between the 'truth' and the 'false'. This idea, of course, depends on the power of discursive process which determine which discourse is taken and which one is not.In doing a research using the Discourse Analysis, the analysis should focus not only on how to find the 'truth' or the 'false' but more on how strong the discursive process works in producing the discourse and turns it into the 'truth'. The work on Discourse Analysis requires us to critically analyze the discourse constructed as the representation of the reality and how that discourse has power to be the 'truth' for the society and seen as something natural through the 'fixed' meaning behind it.

By doing a research using the Discourse Analysis, the notion that there is no 'fixed' meaning must be manifested in mind. There are always other possible meanings constructed by other discourses. The reality that is seen or experienced is something that the representation formed through a discursive process. After all, this representation of reality would lose its power and come back to its form as discourse. At this moment, the struggle between one discourse and another would start again in order to stand as the representation of the reality and the 'truth' for the society for a certain period of time.

\section{DISCUSSION}

\section{The Alluring Voice: Vocal Texture of Hispanic Music in American Pop Song}

When talking about music elements, the timbre has its own significant role in creating the erotic vibe on Hispanic music. According to Jessica Dais (2019), timbre is auditory senses that can be produced both using music instruments and vocal. In bringing out the sensual form of Hispanic music, timbre or tone color produced through vocal seems to be the main actor here. In particular, the various kinds of sound waves produced by human can give color or character to the music. In the case of Hispanic music, the vocal texture from the singers can create the erotic vibe and makes the music sounds sexy.

In the case of creating the sexy voice, there are some discussions about the type of voice which can be considered as sexy. Estevan Q., a Los Angeles-based writer and co-host of the pop culture podcast Your Gay Cousins, in Wong (2019) states that:

For me, there's a certain texture and rhythm to a guy's voice that can be so attractive. It isn't necessarily about a voice being deep, but one that's a bit gravelly, yet breathy - sort of how I imagine whiskey might sound if it had a voice.

Another statement came from Jean Berko Gleason, a co-author of the textbook "Psycholinguistics" and professor emerita at Boston University whom states that "overall, though, a sexy voice is warm and inviting. It feels as if it is spoken from the chest, rather than the head. Its tones are pleasing and not at all nasal"(ibid). Moreover, this type of voice also gives a sense of maturity to the speaker, 
which somehow compliments the sexiness itself.

Related to the discussion of Hispanic music, the explanation of vocal texture or vocal quality brings out the question if there is a certain type of voice or vocal texture considered as suitable in performing Hispanic music. Andaluz (2019) initially states that there is no specific type of voice in singing Hispanic music, especially Flamenco. However, he also lists several types of voice in singing Flamenco based on several Flamenco musicians throughout history. For example, singers such as Manolo Caracol and Maria Borrico have the type of voice called "afillá" which refers to hoarse, brushed, and hard type of voice (ibid). Other singers, such as Tomás Pavón and La Serrana, are another examples of Flamenco singers with a sweet, pasty, and virile type of voice known as "Redonda" (ibid). These two examples together with other types of voice such as "Natural", "Facil", and "Falsete" do not only show the richness of vocal interpretation in Hispanic music but also give the character to this particular music genre. This surely can bring out so many flavors to Hispanic music. Primarily, it can be seen that these Flamenco musicians are remarkably well known not only for their music but also for their vocal textures. Surely, it can be assumed that other musicians from other genres in Hispanic music also have their own remarkable vocal characteristics. On top of that, it even strengthens the idea that vocal quality or vocal texture has its own role in giving color or character to Hispanic music.

Associated with the richness of vocal interpretation, the vocal texture also makes Hispanic music sounds sexy or erotic. In this case, the label of sexiness then becomes the aspect that cannot be taken away from Hispanic music. Moreover, by seeing how strong the sensual formula in Hispanic music also leads to the richness of Hispanic music itself. The expression of sexuality in Hispanic music sort of brings out the soul of the music itself. This state can be found even in American music industry, especially in the process of producing Hispanic music. Through this, it can be seen how the singers of the music try to present the sensuality of the music even by playing around with their vocal texture. Surely, seeing these singers, each of them has their own vocal texture or vocal quality. However, when talking about singing, singers are required to be able to present the song with flavor in it. Not only trying to be in harmony with the music, but they can give more colors to the song, especially using their voice. In order to present the sensuality of Hispanic music, singers have to explore their vocal interpretation. In this case, they cannot treat Hispanic music like other music because they have to bring out the aspect of sensuality or the eroticism, which is strongly attached to this music.

For instance, female singers such as Camila Cabello and Selena Gomez become American singers with their own vocal characteristics different from one another. However, when they produce their own Hispanic music, both of them are able to present the sexiness or the sensuality to the fullest without making such tragic changes to their vocal textures. As a matter of fact, they precisely explore and use their vocal quality to create the sensuality of Hispanic music. The song titled "Havana" (2017) is the example of how the sensuality of Hispanic music is presented. Camila Cabello successfully presents her song in a sensual way. As a singer, she has her own vocal characteristics. Jess Rapir (2020) informs that, similar to Ariana Grande, Cabello has a voice type of a light lyric soprano that presents her with big 
voice but with a youthful quality which also gives a girlish vibe to her song. However, in singing certain songs, such as "Havana", she makes use of her good lower register which helps her in creating a gravelly tone with wellrounded and pleasant quality. This type of voice presents her with more maturity and gives a warm feeling through the song. With this type of voice, Cabello is able to present the song with a sense of sensuality. Moreover, Chris Molanphy (2018) shows that sultry and steamy-sounding song such as "Havana" brings Cabello to the position of No. 1 on Billboard Hot 100 chart. Through this, it can be seen that Camila Cabello successfully presents the erotic formula of Hispanic music, which eventually brings her and this song to popularity.

Another singer such as Selena Gomez also can be taken as another example of having the sensual vocal texture. As a singer, Gomez is categorized as lyric mezzo-soprano with light and girlish tone. Richard S. He (2020) states that even though she has a relatively limitted vocal range, she can deliver it well in a soft, delicate, husky, and whispery tone of voice. With this type of voice, there is no doubt that she can bring the sensual vibe to the song. Moreover, Robinson (2017) explains how the singing style called "whisperpop" becomes the trend in pop music nowadays. Gomez becomes the face of this singing style because she can deliver her whispery and breathy voice very well and this type of voice somehow can create intimacy and deliver any kinds of feeling to the audience. In a case of Hispanic music, this can be seen through a Spanish song titled "Taki Taki" (2018), a record in which Gomez collaborates with DJ Snake, Ozuna, and Cardi B. Gomez was singing in a seductive and flirtatious way by making use of her breathy and whispery voice, which can bring the erotic vibe to the song. As the result,
Herman (2019) shows how this song gets itself popularity by being streamed for more than 49 million by the end of 2018 and another 8 million in 2019. As the singers of Hispanic music in American music industry, these singers are able to maintain the erotic aspect in order to keep the authenticity of Hispanic music. This aspect is also the one that makes Hispanic stand out among other American popular music.

Furthermore, the sensuality of Hispanic music itself is also complemented by the masculinity presented by the male singers. Mirandé (1979) in Andersen and Taylor (2008) states that "Latino men bear the stereotype of machismo - exaggerated masculinity" (p. 312-313). This situation happens in Hispanic music even when it is produced in American music industry. The concept of machismo somehow cannot be taken away from Hispanic music. Larson (2006) states that:

Characteristics of the 'Latin lover' are his 'suavity and sensuality, tenderness, and sexual danger'. [...] The Latin lover stereotype has some positive attributes (sexual prowess and good looks) and some negative ones (hypersexuality and irresponsibility) (p. 60).

The idea of masculinity is always attached to Hispanic men and this is also presented in Hispanic music, in which male singers always show their masculinity through their music. In terms of vocal quality, male singers in Hispanic music stick with the deep, raspy, and breathy voice. This type of voice gives the male singers a mature, masculine, and sensual personality.

As an example, a singer named Luis Fonsi collaborates with so many musicians on creating Hispanic music in American music industry. In some singles such as "Despacito" (2017), "Échame La Culpa" (2017), and 
"Baby" (2018), Fonsi presents himself as a typical masculine Hispanic man. In terms of vocal quality, he is classified as a lyric tenor who has a wide vocal range and a good technique on chest and head voice. In those songs, he can project his voice out loud even on reaching high notes without singing in falsetto. Moreover, in reaching lower notes, he uses his chest register and creates a deep and breathy voice, which gives an intense and warm feeling to the song. Another example can be seen through another singer named Maluma, who is classified as a tenor. He also has a wide range, but compared to Luis Fonsi, he has more breathy and raspy voice which does not only show his masculinity but also enables him to create a flirtatious and seductive voice. Furthermore, the machismo itself is also presented through another element of music, including the verbal element or the lyric that focuses on the man's portrayal full of masculinity. For example, in a song titled "Hey Ma" (2017), a rapper named Pitbull sang his verse that clearly emphasizes the masculinity, especially related to man's personality and their relation with women. By mentioning the popular movie figure such as "James Bond", for example, it can be taken as the way to present a man as the figure of a charismatic, charming, intelligent, and gentle person. In this case, Bond becomes the reference on how a man should be and should act especially towards women.

Larson (2006) also states that “...Latin lovers are typically presented as lighter skinned of the upper class and are more likely to be European than South or Latin American" (p. 60). This statement supports the idea of masculinity in Hispanic music that presents men, especially male singers. in certain way in order to emphasize the masculinity itself and man's sensuality. The phrase "treat you like that queen" and the phrase "the good, I'm that raw, slick on the dong" in the lyric might show the man as a gentle person, especially towards woman also as a sensual figure; good looking and knows how to copulate. Moreover, the concept of masculinity in Hispanic music is also strengthened by the visual element of the music itself. It can be seen through the music video of Hispanic music produced in American music industry in 2017 and 2018 as in Figure 1., Figure 2., and Figure 3., which emphasize how Hispanic music strongly presents the machismo of Hispanic men.

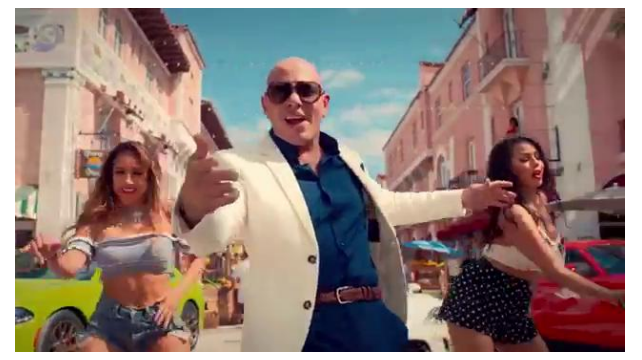

Figure 1. Pitbull's performance with female dancers in "Hey Ma" (2017)

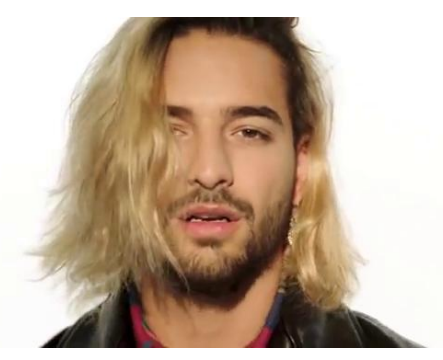

Figure 2. A close-up of Maluma in "Arms Around You" (2018)

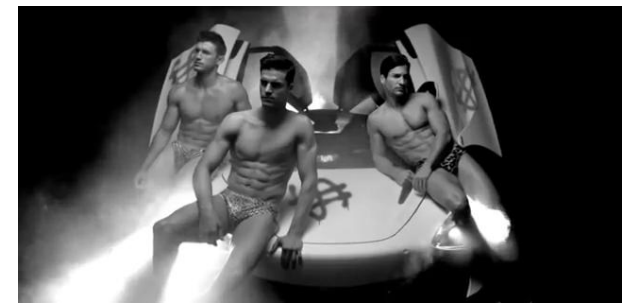

Figure 3. Male models in Jennifer Lopez's "Dinero" (2018)

Through those figures, it can be seen how men are portrayed in Hispanic music with strong masculinity. In terms of appearance, men in Hispanic music are always good looking; handsome with a strong jaw line, look stylish with suits or sunglasses, and look sexy with a sturdy body. This can be another proof on how 
machismo in Hispanic music is built through all the elements of the music. This also becomes the aspect that makes Hispanic music different from other popular music in American music industry. Instead of following shift on the concept of masculinity, Hispanic music still holds on to the concept of hard masculinity.

Cepeda (2018) shows Bad Bunny as one of the musicians who try to break the masculine behavior through their music by carrying the issues about self-reflection, openness, and body positivity, especially for women. However, Cepeda also points out that the concept of machismo is so strong in Hispanic music that even Bunny himself still cannot completely free himself from it (ibid). This can be seen through his music which, at the same time, still objectifies women by pointing out their accents, body features, even ways to copulate with women. The form of strong sensuality in Hispanic music is not only presented through the vocal texture, but also through the other music elements. Furthermore, related to brief discussion on masculinity, Hispanic music indeed has its own way in showing woman sensuality through the music elements. Not only through the vocal texture, the sensuality in Hispanic music is also presented through the other music elements, which lead to a form of woman's body exposure.

\section{Hispanic Body Image: Woman's Body Exposure in American Pop Music}

The discussion about the form of sensuality in Hispanic music is taken further especially on how Hispanic music also presents woman sensuality. Not only through the vocal texture, woman sensuality also can be seen through other aspects such as lyric and music video. Quoted from Guzmán and
Valdivia (2004) as well as Negrón-Muntaner (1991) (in Brooks and Hébert, 2006),

Their [Latinas] sex appeal is played up heavily in music videos. Bright colors, rhythmic music, and olive skin plays a central role. Dominant representation emphasized on the breasts, hips, and buttocks. Desmon calls the Latina body 'an urbane corporeal site with sexualized overdetermination' (p. 303).

Those statements explain how every element in Hispanic music presents women with their sex appeals. In this case, after being explored through sensual vocal texture by female singers, sex appeal itself is even stronger when it is presented through verbal element or visual element such as lyric and music videos. For instance, through lyric and music videos, the sex appealsis brought with a concept of body exposure which shows how certain parts of woman's body are exposed in a certain way in order to present Hispanic woman as a sexy figure.

Moreover, in creating Hispanic music in American music industry, woman's body exposure even becomes the strong factor that brings Hispanic music into popularity. Different from other American popular music, the lyric and music videos of Hispanic music visibly contain the idea of Hispanic woman's sex appeal. In the Spanish version of a song titled "Hey Ma" (2017), for example, Pitbull sang his verse "El vago trabaja doble, so, ponte las pilas. Todo mundo quiere una Cubana, ponte en fila. Esas mujeres están calientes y mucho más. Te queman por aquí, te queman por allá." (Mitchell et al, 2017). If in the English version of this song Pitbull's verse has a strong form of machismo, then in this Spanish version Pitbull focuses on Cuba and the beauty of Cuban women as the charm of the city itself. For instance, by mentioning "el vago" (the bum) the verse precisely puts the attention on certain body part as a form of 
body exposure which also shows how certain body parts such as buttocks are considered as sexually appealing. Moreover, with an additional words such as "trabaja doble" (works double), this verse also underlines how Hispanic women are claimed to be sexier than other women in general. This form of body exposure is also reflected in music videos as shown in Figure 4., Figure 5., and Figure 6, which show how a woman uses body gestures and clothes that accentuate her body curve and beauty.

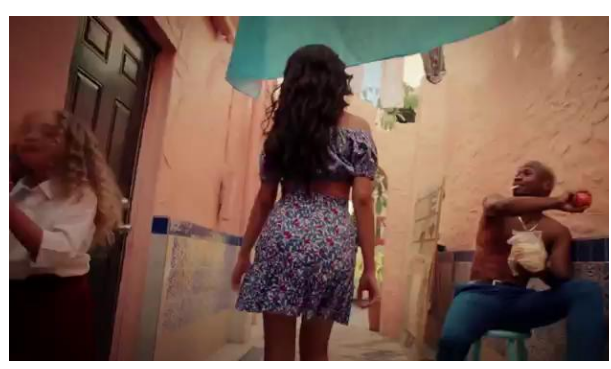

Figure 4. A medium long shot of Cabello in "Hey Ma" (2017)

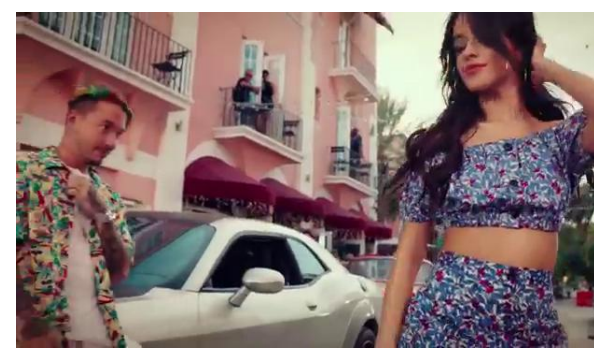

Figure 5. A cowboy shot of Cabello in "Hey Ma" (2017)

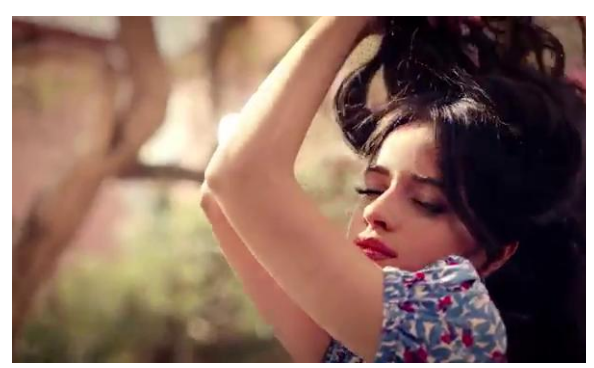

Figure 6. A medium close-up of Cabello in "Hey Ma" (2017)

Related to how the body of Hispanic woman is reflected through the lyric and the music video, Negrón-Muntaner (2004) explains that:
American Popular Music

Yet it was precisely the body, particularly the curves (or, in less poetic boricua street language, el culo), that proved to be the most compelling way to speak about how Latinas are constituted as racialized subjects, what kind of (low) cultural capital is associated with these bodies, and how the body can materialize as a site of pleasure... (p. 232).

It can be understood how Hispanic women's discussion is always associated to their sexual appeals. Their body becomes the center of the attention where they are always seen as sexy and attractive figures. Moreover, in the same song, the phrase "Todo mundo quiere una Cubana, ponte en fila" (everybody wants a Cuban girl, stand in line) can explain how the beauty of Cuban girls or Hispanic women in general are desirable and unbearable for everybody. However, this also can be related to the idea of how Hispanic music somehow materializes the beauty and the body of Hispanic women by putting them as the part of Hispanic exotic culture and somehow giving an idea that the beauty of Hispanic women is something that people can experience and enjoy as the part of experiencing the Hispanic euphoria itself. Furthermore, the representation of women with their sexy body in Hispanic music is taken as the main point that makes Hispanic music stands out in American music industry because the way Hispanic music contains the body exposure also becomes the core of how the American audiences find a different kind of enjoyment and pleasure through the music itself.

The way Hispanic music exposing woman's body itself brings out another issue related to the woman sexual objectification. In an article, Nussbaum (in Baldissarri et al, 2019) states that "sexual objectification is the treatment and perception of seeing women as objects" (p. 2) which is strengthened by the statement from Fredrickson and Roberts 
(1997) who explain that "the objectification is related to the objectifying gaze as the more or less explicit male attitudes, sexual innuendos or comments focusing on women's physical appearance" (ibid). It can be perceived how women are seen as an object rather than as a human especially when their body becomes the center of attention. In this case, seeing women as objects rather than human would also denying the intelligence, the personality, and other qualities possessed by women as human beings.

Woman body exposure in Hispanic music clearly can be seen as the form of women sexual objectification which can show how Hispanic music draws the attention of the audience towards the woman sensuality by exposing the body parts such as breasts, hips, and buttocks. Puleo (in Campos, 2005) states "the woman projected in salsa songs is only represented as a source of pain and pleasure, but never as a person in her own right" (p. 50). This statement related to how music can deliver pain and pleasure to the audience and how woman takes part on that process. It can be perceived that woman does not have control over herself when it comes to music. Music becomes the one that controls woman and moves her body, so she can feel the pain or the pleasure from the music then somehow enables her to deliver the same feelings to the audiece.

Related to the act of woman objectification that clearly identifies woman different from man, Foucault (1995) states that,

Our society is one not of spectacle, but of surveillance; under the surface of images, one invests bodies in depth; [...] it is not that the beautiful totality of the individual is amputated, repressed, altered by our social order, it is rather that the individual is carefully fabricated in it, according to a whole technique of forces and bodies ( $\mathrm{p}$. 217).

Through this, it can be understood how an individual is having a fabricated identity which seems to be taken as the "natural" form of identity. Moreover, it turns out that this fabricated identity is just a collection of images which has its own power in creating the body underneath. Even though Foucault does not directly refer to the gender issue, this statement explains how women are represented in a certain way due to social construction. Beauvoir (in King, 2004) states that, "one is not born, but rather becomes, a woman" (p. 32). In this case, it can be perceived that, woman also consists of various images that create her as an individual according to the social construction itself. However, in the case of woman sexual objectification, the part of social construction especially the concept of masculinity surely has its own role in constructing images of woman which is dragging woman from her individual self and is putting her as an object instead.

In the case of producing Hispanic music in American music industry, woman sexual objectification still can be found easily through the music elements especially the verbal and visual elements. In a song titled "Familiar" (2018), for example, Liam Payne sang his verse "...Your waistline, the bassline. You're shaped like vibrato. A model or some kind of bottle. Well, pour up 'cause I want a taste" (Sabath et al, 2018) which clearly stresses on woman's body curve by using some symbolic or metaphorical words such as "bassline" and "bottle". Related to woman sexual objectification, not only symbolizes woman's body with an object, but also creates the image of woman with curvy body; big breasts, skinny waist, and big bottom. Moreover, the words such as "vibrato" and "pour up" even point out 
how man sees woman as the source of pleasure; the word "vibrato" refers to how woman's sexy body thrills man and the words "pour up" refers to how woman's beauty or body is consumed by man. Another example can be seen in another song titled "Hola" (2017) where Maluma sang his verse "Eres sabrosura pura. Mira qué linda figura. Modela en la orilla de la playa" (Nija et al, 2017) which also shows how man emphasizes the woman's beauty by focusing on the shape of woman's body. This, once again, put woman as an object when the woman's body seems to be consumed by man as the source of pleasure itself.

Related to Foucault's statement mentioned previously, those examples above can show how Hispanic music constructs woman's images by presenting woman as a sensual figure. Moreover, the concept of machismo in Hispanic music clearly strengthens the act of woman sexual objectification itself. In an interview, Foucault (1984) states that:

in human relations, whatever they are; whether it be a question of communicating verbally [...] or a question of a love relationship, an institutional or economic relationship power is always present: I mean the relationship in which one wishes to direct the behavior of another (p. 11).

In the case of Hispanic music, the representation of woman could be the result of human relations. Particularly, in a society of machismo, there is a tendency of woman sexual objectification due to how woman is directed to a certain level where woman is seen as an object of pleasure rather than human. Hispanic music, in this case, surely cannot separate itself from this power relation and even materializes the act of sexual objectification instead.

Deveaux (1994) also emphasizes how Foucault statement about the power in human relation also carries the idea of sexual subjectification.

This entails a discussion of Foucault's treatment of the subject [...] Foucault emphasizes that in order for a power relationship to exist, the subject on whom that 'conduct'...is exercised must be a free subject [...] a subject must be capable of action or resistance and be recognized as a person on whom force or 'conduct' is exercised (p. 233).

Through this, it can be assumed that woman is not entirely passive in responding to the process of power relation itself. Even though Foucault has pointed out that no one can be free from the forces of power relations, he also accentuates that the only way power relation exists is when both parties are considered subjects with their free will. Related to woman sexual objectification, it is undeniable that woman is being objectified as the result of the male dominant power. However, in experiencing the sexual objectification, women have their own free will in reacting or taking an action as a subject of the act itself. This leads to the idea of woman sexual subjectification which, instead of doing selfobjectification, women can see themselves as a subject with their own free will and does not lose their sense of self.

In producing Hispanic music, especially in American music industry, the idea of woman sexual objectification surely puts up an issue especially following the idea of postfeminist sensibility, which shows the shift from women as sexual objectification to women as sexual subjectification. Rosalind Gill (2007) proposes the notion of postfeminist sensibility and explains new notions on postfeminist discourses. One of them is the shift from objectification to subjectification. Particularly, Gill (2007) states that:

...postfeminist sensibility [...] represents a shift in the way that power operates: a 
shift from an external, male judging gaze to a self policing narcissistic gaze. [...] In this regime power is not imposed from above or from outside, but constructs our very subjectivity (p. 9-10).

Through this statement, it can be seen how the perspective on presenting woman, especially on the media, is changing. The postfeminist sensibility shows how media nowadays presents woman as an active, confident, and assertive subject, especially on presenting woman sexuality. In a song titled "I Like It", Cardi B (2018) sang her verse "They call me Cardi Bardi, banging body. Spicy mami, hot tamale. Hotter than a Somali, fur coat, Ferrari"(Kingz et al, 2018) that clearly shows how confident she is especially with her body. It is clear that she uses metaphorical or symbolical words on her verse and all of those words symbolize her own body and shows how proud she is with her looks. Expressions such as "banging body", "spicy mami", and "hot tamale" refer to the figure of sexy women with a desirable body who always become the center of attention and the beauty queen among other women.

The same concept also can be seen in another song titled "Mi Gente" (2017) which shows Beyoncé sang her verse as follow:

He say my body stay wetter than the ocean. And he say that Creole in my body is like a potion. See these double Cs on this bag, murda. Want my double Ds in his bed, Serta. Soon as I walk in/Boys start they talkin'. Right as that booty sway (Mohombi et al, 2017).

When talking about the big idea of the song, this song is clearly dedicated to Hispanic or people, which can be seen through the title "Mi Gente" or my people. However, in Beyoncé's verse, she clearly talked about her body curve. The phrase "my body stay wetter than the ocean" shows how her body is always full of passion. The phrase "Creole in my body is like a potion" explains how a woman with
Creole (European - African Creole) identity is considered as attractive and sexy which can easily attract men which is complemented by the words "double Cs", "double Ds", and "booty" to expose her body parts such as big breasts and big bottom as the attractive and desirable parts of her body especially for men.

Moreover, this idea also can be seen through visual elements or the music videos as in Figure 7., Figure 8., and Figure 9. where female singers or women in music videos confidently show their body curve as the part of their individuality.
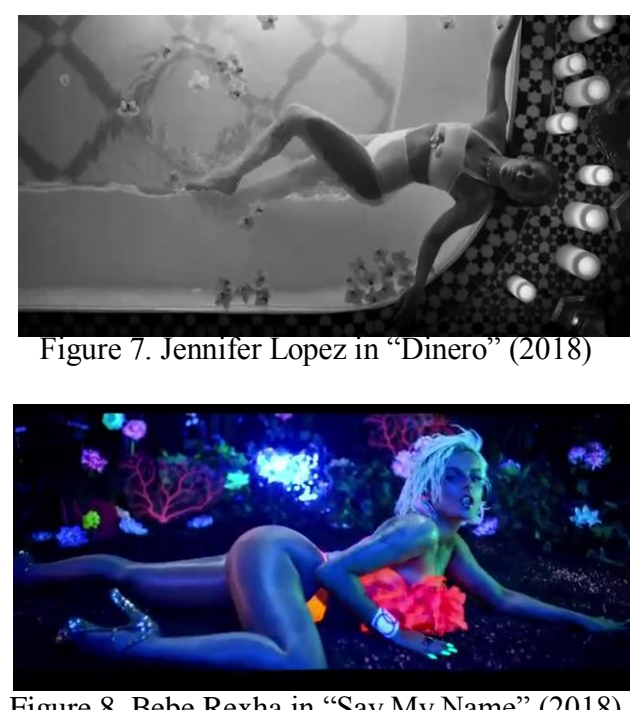

Figure 8. Bebe Rexha in "Say My Name” (2018)

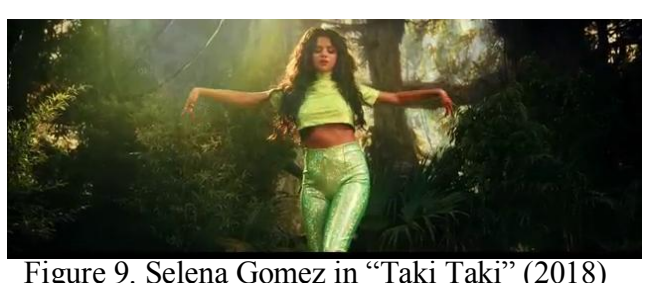

Through those figures, it can be seen how female singers or women in Hispanic music perform with so much confidence with their body. Showing their body curve by wearing clothes and expose their skin or their body parts such as their breasts, belly, bottom, or legs. Moreover, they also pose in certain ways, which also accentuate their body curve. 
Even so, it is possible that these examples are related to the concept of male gaze, which indicate that these women show their bodies asan objectification. However, the way women appear in music videos cannot be separated from the fact that the idea of woman subjectification starts to rise among the society and the way women appears in music video also becomes one of the result or the examples on how media respond and follow the emergence of woman subjectification in the society. Related to those examples, it can be perceived that even though Hispanic music in American music industry tries to stick to the concept of machismo, it can also present woman sexual subjectification which seemed to be suitable with the thought of postfeminism. Furthermore, in an article, Riley et al (2017) states that:

... femininity as a bodily property produced through practices that required self-surveillance and appearance related bodywork, making the body the locus of women's success and identity (p. 6) [...] directed women's desire towards working on themselves in ways that allowed them to take up new sexual subjectivities as their own (p. 10).

It can be understood that the way woman is presented in Hispanic music is not merely body exposure but is also about woman empowerment, especially on their sexuality and their subjectivity. This shows that even though this aspect is contradictory to machismo in Hispanic music, somehow American music industry can present changes and follow the social dynamic without totally changing the concept of machismo in Hispanic music; American music industry can make these two concepts complement each other. Moreover, the discussion on the form of sensuality in Hispanic music is taken further into the music theme where Hispanic music presents the intimacy between man and woman, which does not only follow the idea of love themed song as popular music but also strengthens the sexiness on Hispanic music.

\section{Hispanic Love-themed Song in American Music Industry: Passionate and Intimate Love}

Talking about popular music, one aspect that cannot be separated from the characteristics of popular music is the music theme. Theme in music does not only refer to the recognizable melody, but also to the character of music which can be seen through the meaningful lyrics or even the conceptual music videos. The role of lyrics is delivering the emotion and the message of the song. Surely, melody also has its role in expressing the music, but the words used in the whole lyrics definitely have a big part in delivering the emotion and the message of the music. In this situation, creating popular music demands the ability on composing the lyric, which can attract the audience and able to create the connection between the song and the listeners. Among various ideas on music theme, love stories become the most likable idea, especially for popular music. Madanikia and Kim (2014) analyze the top of 40 songs throughout nine years in order to see the shift of music themes, especially the ones with love theme. They explain that:

Themes of love were more common than those of lust, with $62 \%$ of lyrics containing a love theme and 39\% containing a lust theme. [However] from 2001 onward, a shift toward themes of lust only becoming more common and outstripping themes of lust and love combined. [...] These changes reflect a growing cultural acceptance towards sexuality outside of the constraints of committed romantic relationship (p. 5).

It can be understood love theme becomes the formula of popular music, which easily attracts audiences. This is surely related to how the audiences can relate their feelings to the 
music, especially when it talks about romance because of the pleasure and satisfaction the music brings for the audiences. At the same time, it can be seen how popular music also emphasizes social changes, especially on the idea of sexuality. This situation shows how the audience nowadays also embrace the idea of sexuality. They can also celebrate that by enjoying the popular music.

The discussion on sexuality in Hispanic music is taken further into how Hispanic music combines love with lust into one theme, which makes the music sounds intimate and sensual at the same time. This can certainly be seen through the meaningful lyrics that show how the sexual intimacy in Hispanic music itself might show how men and women are full of confidence in showing their sexual admiration towards each other, which includes touching, kissing, and even sexual intercourse. In a song titled "Despacito" (2017), for example, Justin Bieber sang his verse "You fit me 'tailor-made' love, how you put it on. Got the only key, know how to turn it on. The way you nibble on my ear, the only words I wanna hear. Baby, take it slow so we can last long" (Bear et al, 2017), which clearly shows how two individuals are attracted to each other since their first encounter. The phrase "The way you nibble on my ear, the only words I wanna hear" clearly shows the sexual interaction already happened and includes physical contact, which also shows the intimate relationship between them. Moreover, through the phrase "Baby, take it slow so we can last long" also might emphasize the desire for a romantic and committed relationship. Furthermore, in an interview taken from YouTube, Fonsi (2017) explains that this song presents how these two individuals could not control themselves but decided to build the relationship slowly to keep it passionate and intimate.
However, there are songs such as David Guetta's "Goodbye" (2018) and "Say My Name" (2018) which also contain Hispanic music rhythm, such as Latin pop and Reggaeton. Moreover, related to the form of sensuality, these songs also contain the concept of man and woman sensuality with the concept of eroticism through body exposure. However, in the case of love theme song, these songs present love in different way, which lean more into love separation or heartbreak that even more focuses on presenting the love aspect without really presenting the lust in it. In this case, the absence of lust in these songs somehow affects the form of sensuality or the eroticism in these songs, especially when they try to show the elements of Hispanic music.

Moreover, in terms of popularity, these songs seemed to be less popular compared to two previous songs. Back to previous examples, "Despacito" (2017) and "Hey Ma" (2017), these two songs combine love and lust at the same time, which strengthens the eroticism or the sensuality on the music. As the one which also starts the hype of Hispanic music in American music industry, "Despacito" (2017), especially the remix version featuring Justin Bieber, got up to 619 million streams on Spotify and more than 427 million streams on YouTube (Musicbusessworldwide.com). At the end of the summer 2017, "Despacito" places the number one in Spotify's Global Top 30 Songs of the Summer and in Spotify's U.S. Top 30 Songs of the Summer (Darville, 2017) also at the end of 2018, it reaches the 4th position for US Dance/Mix Show Airplay and the 7th for US Mainstream Top 40 (Billboard.com, 2018).

On the other hand, "Goodbye" (2018) appeared in 10 charts, it got the peak position for \#7 on 6 October 2018, but then it reaches \#30 in US Hot Dance/Electronic Songs at the 
end of 2018 and down to \#79in the end of 2019 (Billboard.com). As for "Say My Name" (2018), it appeared on \#13 music charts, it got the peak position for \#8 on 26 January 2019, but then it reaches the 91st position in US Hot Dance/Electronic Songs at the end of 2018 and \#39 in the end of 2019 (Billboard.com). Through the provided examples and the explanation, how lyric has its role in creating the love theme in the songs can be understood. By containing the sensual lyric and portraying sexual interaction between man and woman surely strengthen the form of sensuality as one of Hispanic music and surely contribute to the popularity of the music itself.

The ideas of intimacy and passion as the concept of love theme in Hispanic music are even getting stronger when it is applied into the visual form or the music video. First of all, when talking about the visual element of Hispanic music in general, there is a big concept often appears in the music video,such as a concept of a huge party. In this case, seen through the previous examples of figures, most Hispanic music videos present a concept of a party or a music festival that involves so many people. Simply saying, the concept of a party itself shows the festivity of Hispanic music itself. For instance, the settings in music videos that seem crowded where people talking, drinking, singing, and dancing also contain the energy of the music itself and follows the music's dynamic. Moreover, the high interaction and energy presented in the music video can also emphasize passion or intimacy, especially when the music videos follow the dynamic of the music itself. Precisely, instead of focusing only on the singers, the music videos tend to focus on showing the surrounding, which seems intense with people dancing around.
American Popular Music

As in Figure 10., Figure 11., and Figure 12., it can be seen how the music videos do not only show the dynamic of the music but also support the love theme, especially on presenting the intimate and passionate interaction between men and women. These figures are taken from Hispanic music videos produced in American music industry, which is full with the uniqueness of Hispanic music. These figures present the motion of Hispanic music, which certainly have different concept from the other American popular music in American music industry.
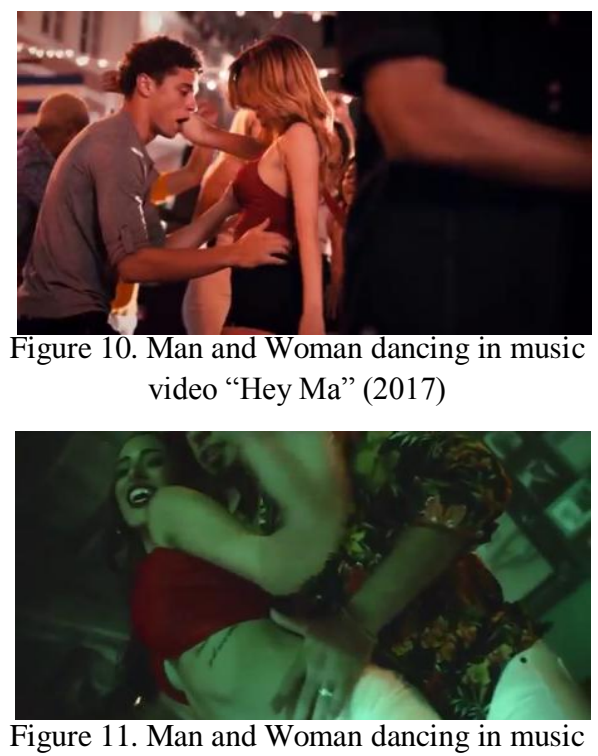
video of Cardi B's "I Like It" (2018)

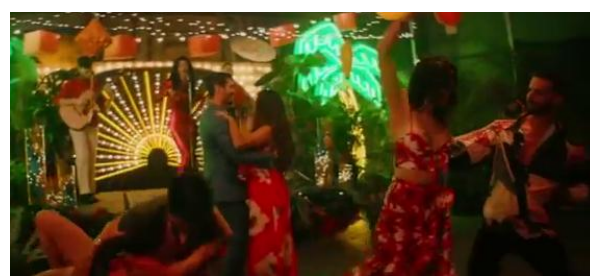

Figure 12. Men and Women dancing in music video of Clean Bandit's "Baby" (2018)

Through those figures, it can be seen how music videos do not only show the dynamic of Hispanic music with its rhythms and music instruments, which make people dance along, but it also shows how the interaction between men and women could start with dancing together. In terms of setting, the music videosare set in public places such as bars, beaches, and even on the streets, indicating 
that anyone could join the party. In this case, any strangers could interact with each other, and the music might bring them to dance. Through those figures, it can be seen that men and women interact with their bodies; they dance together not only follow the rhythm of the music, but they also synchronize their bodies. Clearly, while enjoying the music, men and women do not hesitate to involve touching, holding, even being so close to each other.

Moreover, in a book titled Afro Latin Rhythm Romance Dance, Gary Sowell (2014) states that:

The man must always pay attention to the lady. Most Latin dances are romantic, rhythmic partnerships, and it is the man's job to make the woman feel desirable. All of his attention and energy should be directed toward his dance partner while they are on the floor. [...] The two should maintain eye contact with each other at all times (p. 83-84).

Through this quotation, it can be understood how men and women engage with each other while enjoying the music. Precisely, it is related to the discussion on body figures, which also shows how women with body curves do not only move their body and accentuate their body curves but also let men touch their body, hold their waist, or lead their body to move. Therefore, they will show the increased tension and dance in a passionate way. In this case, the music video of Hispanic music not only supports the exotic side of Hispanic music but also presents the erotic side of Hispanic music; dimmed light, smoky, dark room does not only emphasize the exoticism of the music but even strengthens the aspects of eroticism.

In terms of popularity, there is no doubt that the music video has its own significant role in supporting the popularity of the music itself. Reflected by the above examples, songs such as "I Like It" (2018), "Baby" (2018), and "Hey Ma" are packed into music videos, which also gain the attention from audiences especially on global video streaming platform. As for Cardi B's "I Like It", the music video portrays the nightlife in Hispanic neighborhood, which shows people partying and dancing around the neighborhood and in a bar. This videos was released in 29 May 2018 on YouTube, and since then the music video gains more than 1 billion views. Comes with different concept, the music video of Clean Bandit's "Baby" portrays the Hispanic wedding, started with ceremonial wedding in church and ended with a reception in a bar where people playing music and dancing together. This video was released in 2 November 2018 on YouTube and already got more than 228 million views. Another concept also comes from the song "Hey Ma" (2017), which was released as one of the soundtrack for the movie "The Fate of the Furious" (2017) in two versions, English and Spanish. This music video does not only portray a little bit detail of the movie, but the whole idea is portraying the life in Hispanic society, especially Cuba by showing people dancing and partying together in the middle of the street around the neighborhood. This music video of the Spanish version was released in 10 March 2017 on YouTube, and already got more than 380 million views while the music video of the English version was released in 7 April, 2017 on YouTube and got up to 16 million views. Through this, it can be understood how the love theme reflected in music videos does not only strengthens the form of sensuality in Hispanic music but it also has its own significant contribution in supporting the popularity of the Hispanic music especially in American music industry. 


\section{CONCLUSION}

Keeping the authenticity of Hispanic music is one of the important factors. Even when it is produced in Hispanic music, it is important to make it sound and look as authentic as possible. This is also related to how this music can attract the Hispanic audience.

Another important factor behind the popularity of Hispanic music is the form of modernisation. The form of modernisation in here is related to how formula of American popular music still can be found in Hispanic music. This is also related to how this music can attract global audience by following the dynamic in American society without completely losing its authenticity.

\section{REFERENCES}

(2018) "'Say My Name' David Guetta, Bebe Rexha \& J Balvin." Billboard. Retrieved from www.billboard.com/music/davidguetta/chart-history/DAN/song/1097821.

(2018). “'Goodbye'Jason Derulo X David Guetta Featuring Nicki Minaj \& Willy William." Billboard. Retrieved from www.billboard.com/music/jasonderulo/chart-history/BEL/song/1095776.

Andaluz, El Palacio. (2019 September, 26). "The Voice in Flamenco Singing." El Palacio Andaluz. Retrieved from elflamencoensevilla.com/en/voice-inflamenco-singing/.

Andersen, Margaret L., and Howard Francis Taylor. (2008). Sociology: Understanding a Diverse Society. Wadsworth/Thomson Learning.

B, Cardi. "Cardi B, Bad Bunny \& J Balvin - I Like It [Official Music Video]." (2018 May, 29). Youtube. Retrieved from https://www.youtube.com/watch?v=xTIN MmZKwpA

Baldissarri, Cristina, et al. (2019 August, 8). "So Self-Objectified Women Believe
American Popular Music

Themselves to Be Free? Sexual Objectification and Belief in Personal Free Will." Frontiers in Psychology, 10(1867). Retrieved from www.frontiersin.org/articles/10.3389/fpsy g.2019.01867/full.

Bandit, Clean. (2018 November, 2). "Baby (feat. Marina \& Luis Fonsi) [Official Video]." Youtube. Retrieved from https://www.youtube.com/watch?v=hlznp xNGFGQ

Bear, Poo, et al. (2017 April, 17). Luis Fonsi \& Daddy Yankee (Ft. Justin Bieber) Despacito (Remix)." Genius. Retrieved from genius.com/Luis-fonsi-and-daddyyankee-despacito-remix-lyrics.

Brooks, Dwight E., and Lisa P. Hébert. (2006). "Gender, Race, and Media Representation." The SAGE Handbook of Gender and Communication, edited by Julia T. Wood and Bonnie J. Dow, Sage Publications. 297-318.

Campos, Darshan Elena. (2005). "Albita's Queer Nations and U.S. Salsa Culture." Beyond the Frame: Women of Color and Visual Representation, edited by Neferti X. M. Tadiar and Angela Y. Davis, Palgrave Macmillan. 49-60.

Cepeda, Eduardo. (2018 August, 8). "Latin Trap Rapper Bad Bunny Is Redefining Masculinity In A Genre Steeped In Machismo." WBUR, WBUR. Retrieved from

www.wbur.org/artery/2018/08/08/latintrap-bad-bunny-masculinity.

Dais, Jessica. (2019 March, 8). "What Is Timbre in Music and the Voice? Why Is It Important?" TakeLessons Blog. Retrieved from takelessons.com/blog/what-istimbre-in-music-z02/.

Darville, Jordan. (2017 August, 31). "Here Are Spotify's Most Streamed Songs Of Summer 2017 In Playlists." The FADER, The FADER. Retrieved from www.thefader.com/2017/08/31/spotifymost-streamed-songs-of-summer-2017playlist. 
Deveaux, Monique. (1994). "Feminism and Empowerment: A Critical Reading of Foucault." Feminist Studies, 20(2), 223247. Women's Agency: Empowerment and the Limits of Resistance.

Foucault, Michel, and Gilles Deleuze. (1980). "Intellectuals and Power." Language, Counter-Memory, Practice: Selected Essays and Interviews, edited by Donald F. Bouchard, translated by Donald F. Bouchard and Sherry Simon, by Michel Foucault, Cornell Univ. Press. 205-217.

Foucault, Michel. (1977). Discipline and Punish: The Birth of the Prison. Vintage Books.

Genius. (2017 May, 19). "Luis Fonsi "Despacito" Official Lyrics \& Meaning Verified." Youtube. Retrieved from https://www.youtube.com/watch?v=t9OKl HH6BwM

Gill, Rosalind. (2007 May, 1). "Postfeminist Media Culture: Elements of a Sensibility." European Journal of Cultural Studies, 10(2), 147-166. Retrieved from journals.sagepub.com/doi/10.1177/136754 9407075898.

He, Richard S. (2020 January, 9). "Selena Gomez's Road to 'Rare': How Pop's Quietest Singer Began to Raise Her Voice." Billboard. Retrieved from www.billboard.com/articles/columns/pop/ 8547671/selena-gomez-rare-careerreview.

Herman, James Patrick. (2019 November, 27). "Hitmaker of the Month: How Geffen's Neil Jacobson Took 'Taki Taki' to the Finish Line." Variety, Variety. Retrieved from variety.com/2019/music/news/djsnake-taki-taki-selena-gomez-ozunacardi-b-about-the-hit-song-1203113681/.

King, Angela. (2004). "The Prisoner of Gender: Foucault and the Disciplining of the Female Body." Journal of International Women's Studies, 5(2), 2939.

Kingz, Weezy, et al. (2018 April, 6). "Cardi B, Bad Bunny \& J Balvin - I Like It."
Genius. Retrieved from genius.com/Cardib-bad-bunny-and-j-balvin-i-like-it-lyrics.

Larson, Stephanie Greco. (2006). Media \& Minorities: The Politics of Race in News and Entertainment. Rowman \& Littlefield.

Lopez, Jennifer. (2018 May, 24). "Dinero ft. DJ Khaled, Cardi B.” Youtube. Retrieved from

https://www.youtube.com/watch?v=aEM2 kOrrNJI

Luis Fonsi. (2017). "Despacito - Remix." Despacito Feat. Justin Bieber (Remix), Republic Records (RBMG/Def Jam Recordings), Spotify. Retrieved from https://open.spotify.com/album/3Gq2Dme 9nesdgoqNNlcN8O

Madanikia, Yasaman, and Kim Bartholomew. (2014 July, 1). "Themes of Lust and Love in Popular Music Lyrics from 1971 to 2011." SAGE Open, 4(3). Retrieved from journals.sagepub.com/doi/10.1177/215824 4014547179 .

Mitchell, John, et al. (2017 March, 10). "Pitbull \& J Balvin (Ft. Camila Cabello) Hey Ma (Spanish Version)." Genius. Retrieved from genius.com/Pitbull-and-jbalvin-hey-ma-spanish-version-lyrics.

Mohombi, et al. (2017 September, 28). "J Balvin \& Willy William (Ft. Beyoncé \& Blue Ivy Carter) - Mi Gente (Beyoncé Remix)." Genius. Retrieved from genius.com/J-balvin-and-willy-williammi-gente-beyonce-remix-lyrics.

Molanphy, Chris. (2018 January, 27). "America's New No. 1 Song Is the 'Crazy in Love' of Its Moment." Slate Magazine, Slate. Retrieved from slate.com/culture/2018/01/why-camilacabellos-havana-is-no-1-on-the-hot100.html.

Music Business Worldwide. (2017 July, 20). "Despacito Storms Past 5bn Streams Milestone as Latin America Takes Flight." Music Business Worldwide. Retrieved from

www.musicbusinessworldwide.com/despa 
cito-storms-past-5bn-streams-milestonelatin-america-takes-flight/.

Negrón-Muntaner Frances. (2004). Boricua Pop: Puerto Ricans and the Latinization of American Culture. New York Univ. Press.

Nija, et al. (2017 November, 17). "Flo Rida (Ft. Maluma) - Hola." Genius. Retrieved from genius.com/Flo-rida-hola-lyrics.

Pérez Louis A . (2012). On Becoming Cuban: Identity, Nationality, and Culture. University of North Carolina Press.

Pitbull, J Balvin. (2017 March, 10). "Hey Ma $\mathrm{ft}$ Camila Cabello (Spanish Version | The Fate of the Furious: The Album). Youtube, uploaded by Warner Música. Retrieved from

https://www.youtube.com/watch?v=UWL r2va3hu0

Pump, Lil. (2018 November, 16). "XXXTENTACION \& Lil Pump ft. Maluma \& Swae Lee - "Arms Around You" (Official Music Video)." Youtube. Retrieved from https://www.youtube.com/watch?v=tLNO ce4Y4uc

Rapir, Jess. (2020 March, 27). "Camila Cabello, Ariana Grande Different Speaking And Singing Voices Explained." Business Times, Business Times. Retrieved from www.btimesonline.com/articles/129261/2 0200327/camila-cabello-ariana-grandedifferent-speaking-and-singing-voicesexplained.htm.

Riley, Sarah, et al. (2008). "A Critical Review of Postfeminist Sensibility." European Journal of Cultural Studies, 10(2), 147166.

Robinson, Peter. (2017 November, 11). “"Whisperpop': Why Stars Are Choosing Breathy Intensity Over Vocal PaintStripping." The Guardian, Guardian News and Media. Retrieved from www.theguardian.com/music/2017/nov/11 /whisperpop-why-stars-choosing-breathyintensity-over-vocal-paint-stripping.
Sabath, Mike, et al. (2018 April, 20). "Liam Payne \& J Balvin - Familiar." Genius. Retrieved from genius.com/Liampayne-and-j-balvin-familiar-lyrics.

Sowell, Gary. (2014). Afro Latin Rhythm Romance Dance. AuthorHouse.

Wong, Brittany. (2020 April, 15). "Here's What Makes A Voice Sexy (Or Deeply Unsexy)." HuffPost, HuffPost. Retrieved from www.huffpost.com/entry/sexyvoice-science-men-andwomen_1_5d1bba71e4b07f6ca5857392. 